to generation, certain habits prevailing in certain communities in consequence neither of inherited instincts nor of individual experience, but simply because the young ones imitate what they see in their elder fellows?

As is well known, the stingless honey-bees (Melipona and Trigona) build horizontal comts consisting of a single layer of cells, which, if there is plenty of space, are of rather regular shape, the peripheral cells being all at about the same distance from the first built central one. Now, on February 4, 1874, I met with a nest of a small Trigona ("Abelha preguicosa ") in a very narrow hole of an old canella-tree, where, from want of space they were obliged to give to their combs a very irregular shape, corresponding to the transversal section of the hole. These bees lived with me, in a spacious box, about a year (till February 10, 1875), when perhaps not a single bee survived of those which had come from the canella-tree; but notwithstanding they yet continued to build irregular combs, while quite regular ones were built by several other communities of the same species, which I have had.

The following case is still more striking. In the construction of the combs for the raising of the young, as well as of the large cells for guarding honey and pollen, our Meliponce and Trigonce do not use pure wax, but mix it with various resinous and other substances, which give to the wax a peculiar colour and smell. Now I had brought home from two different and distant localities two communities of our most common Melipona (allied to $M$. marginata), of which one had dark reddish-brown, and the other pale yellowish brow $\mathrm{n}$ wax, they evidently employing resin from different trees. They lived with me for many years, and either community continued, in their new home, to gather the same resins as before, though now, when they stood close together, any tree was equally accessible to the bees of either community. This can hardly be attributed to inherited instinct, as both belonged to the same species, nor to individual experience about the usefulness of the several resins (which seemed to serve equally well), tut only, as far as I can judge, to tradition, each subsequent generation of young bees following the habits of their elder sisters.

Blumenau, St. Catharina, Brazil, November I4, I882

\section{The Inventor of the Incandescent Electric Light}

IN the "Notes" of Nature, vol. xxvii. p. 209, M. de Chagny is described as "the first electrician who attempted to manufacture incandescent lamps in vacuo about twenty years ago." This invention and its successful practical application (irrespective of cost) was made by a young American, Mr. Starr, and patented by King in 1845. A short stick of gas-retort carbon was used, and the vacuum obtained by connecting one end of this with a wire sealed through the top of a barometer tube blown out at the upper part, and the other end with a wire dipping into the mercury. The tube was about thirty-six inches long, and thus the enlarged upper portion became a torrecellian vacuum when the tube was filled and inverted. I had a share of one eighth in the venture, assisted in making the apparatus and some of the experiments, and after the death of Mr. Starr all the apparatus was assigned to me. I showed this light (in the original lamp) publicly many times at the Midland Institute, Birmingham, and on two occasions in the Town Hall, all of them more than twenty years ago. The light was far more brilliant, and the carbon-stick more durable, than the flimsy threads of the incandescent lamps now in use. It was abandoned solely on account of the cost of suprlying the fower. As a steady, reliable, and beautiful light, its success was complete. In "A Contribution to the History of Electric Lighting," published in the Fournal of Science, November 5, 1879, and reprinted lately in my "Science in Short Chapters," may be found further particulars concerning this invention and its inventor.

Stonebridge Park, N.W.

\section{The Reversion of Sunflowers at Night}

WHILE the fact that sunflowers turn their faces toward the sun in its course during the day is as old as our knowledge of the plant, I am not aware that any record has been made as to the time of night that they turn fo the east again after their obeisance to the setting sun.

One evening during a short stay at a village in Colorado, in the summer of $\mathbf{I} 88 \mathrm{r}$, I took a walk along the banks of a large irrigating ditch just as the sun was setting. The wild variety of Helianthus annuus, Lin. ( $=$ H. lenticularis, Douglass) grew abundantly there, and I observed that the broad faces of all the flowers were, as is usual in the clear sunset, turned to the west. Returning by the same path less than an hour afterwards, and immediately after the daylight was gone, I found, to my surprise, that much the greater part of these flowers had already turned their faces full to the east in an icipation, as it were, of the sun's rising.

They had in that short time retraced the semi-circle, in the traversing of which with the sun they had spent the whole day. Both the day and night were cloudless, and apparently no unusual conditions existed that might have exceptionally affecterl the movements of the flowers.

Idoubt not that many persons like myself have supposed that sunflowers remain all night with their faces to the west, as they are when the sunlight leaves them, and until they are constrained by the light of the rising sun, to turn to the east again. It is not my purpose to offer any explanation of the cause of the phenomenon here recorded, but it seems to me improbable that it could have been an exceptional instance; and I only resret that no opportunity has since occurred to me to repeat the observation.

Washington, December 26

C. A. White

\section{Pollution of the Atmosphere}

Mr. H. A. Phillips, in Nature, vol. xxvii. p. I27, thinks that the effect of the increasing quantity of hydrocarbons in the air from the combustion of coal will be to make climates more extreme. It seems to me the effect will be the direct contrary. Gaseous and vaporous hydrocarbons absorb heat much more powerfully than air, and whatever makes the atmosphere absorb and retain more solar heat than at present will tend to equalise temperatures between day and night, and also between different latitudes. I.think, however, that any possible effect of hydrocarbons will be quite insignificant in comparison with the effect of the watery vapour of the atmosphere, which, as Tyndall bas shown, moderates climates by its power of absorbing solar heat. JOSEPH JOHN MURPHY

Old Forge, Dunmurry, Co. Antrim, December 28, 1882

\section{A "Natural" Experiment in Complementary Colours}

ON page 79 of vol. i. of the "Life, Letters and Journal of Sir Charles Lyell," his visit to the Fail of the Rhine at Schaffhausen is described, and he notes that "as the sun shone on the foam it took very much the rose-coloured tint so remarkable on the snow in the Alps."

His experience as regards the colour being observed in the full sunlight seems to differ from that of Mr. Chas. T. Whitmell, which you published in NATURE, vol, xxvi. p. 573

Moor End, Kersal, near Manchester, January 8 E. J. BLES

\section{BAIRDS' HARE AND ITS HABITS}

SEVERAL instances have been recorded in which individual male mammals have produced milk from their mammary glands for the nutriment of their young. But that the young of a mammal should be ordinarily suckled by the male parent is such an extraordinary anomaly that it is very hard to believe it. Yet that such is the case in an American species of hare (Lepus bairdii) would seem to be highly probable from observations made by Dr. Hayden and his party during one of their expeditions in the Yellowstone Mountains. In the last number of the American Naturalist, Mr. Lockwood gives the following details on this curious subject :-

"In the months of May and June, 1860, Prof. F. V. Hayden and his party of United States explorers found themselves up in the Alpine snows of the Wind River Mountains, where they were detained several days in an attempt to feel their way to the Yellowstone. On May 3I Dr. Hayden declared that a new species of hare was around, as he had observed unusually large hare-tracks in the snow. As the Doctor expressed himself to us :The tracks were very large, the feet being wide-spread, and the hair thick between the toes, thus really furnishing 